\title{
Micronutrient and Phytic acid Contents of Wild Edible Fruits Collected from Temcha Watershed of Amhara Region (Ethiopia) to Combat Hidden Hunger
}

Haimanot Terefe Reta ( $\nabla$ rhaimanot@gmail.com )

Debre Markos University https://orcid.org/0000-0003-2613-5803

Sebsebe Demissew

Addis Ababa University College of Law and Governance Studies

Zemede Asfaw

Addis Ababa University

Ashagrie Zewdu

Addis Ababa University College of Law and Governance Studies

Research article

Keywords: Micronutrients, temcha watershed, wild edible fruits

Posted Date: August 31st, 2019

DOI: https://doi.org/10.21203/rs.2.13723/v1

License: (1) This work is licensed under a Creative Commons Attribution 4.0 International License.

Read Full License 


\section{Abstract}

Abstracts Background: Locally available and easily accessible, underused complementary foods including wild edible fruit species are affordable and potentially more acceptable than other options to address the problem of 'hidden hunger' or micronutrient deficiency. Study aimed to collect and determine the nutritional composition of wild edible fruits with its bioavailability collected from Temcha watershed. Methods: Semi structured interviews were administered to collect all wild edible plants and its associated knowledge through the participation of informants systematically selected from six sub districts in the study area. Mineral and pyhtate content and molar ratio of phytate to mineral ratio were determined using standard methods. Results: Based on the total use value of all wild edible plants, the top 18 wild edible fruits were selected for dietary analysis. The zinc contents of the analyzed fruits were ranged in between $0.06 \pm 0.02 \mathrm{mg} / 100 \mathrm{~g}-88.89 \pm 0.42 \mathrm{mg} / 100 \mathrm{~g}$. The iron content of the analyzed fruits were ranged in between $5.84 \pm 0.00 \mathrm{mg} / 100 \mathrm{~g}-148 \pm 0.93 \mathrm{mg} / 100 \mathrm{~g}$ and the calcium contents were in between $53.25 \pm$ $0.45 \mathrm{mg} / 100 \mathrm{~g}-1280 \pm 0.77 \mathrm{mg} / 100 \mathrm{~g}$. The phytate content of each fruits were ranged in between $6.9 \pm$ $0.00 \mathrm{mg} / 100 \mathrm{~g}-51.4 \pm 0.04 \mathrm{mg} / 100 \mathrm{~g}$. Conclusions: Combination of Ficus sycomorus and either of all wild edible fruits satisfy the daily-recommended allowance of calcium for male and female age 10-18 $(1300 \mathrm{mg} / 100 \mathrm{~g})$. Almost all WEFs provides optimum amount of iron for Children up to 10 years required 11.6 - $17.8 \mathrm{mg} /$ day except Embelia schimperi, Ficus sur, Rossa abyssinica, Rubus studinary \& Ximenia americana. The different amount of zinc $(0.66-89 \mathrm{mg} / 100 \mathrm{~g})$ contributes to control progressive stunting in children in the study area. The phytate concentrations of wild edible fruits do not have a negative impact on the bioavailability of calcium, iron and zinc. The micronutrient content of wild edible fruits provided a lot of contribution for the study area communities and those who shared similar feeding culture elsewhere in the country. Key words: Micronutrients, temcha watershed, wild edible fruits,

\section{Background}

Deficiencies of micronutrients are a major global health problem. More than 2 billion people in the world today are estimated to be deficient in key vitamins and minerals, particularly vitamin A, iodine, iron and zinc (WHO, 2001a). Energy-rich staple crops assure caloric adequacy, and policy makers have historically made them a focus in the quest for global food security. However, staples, generally derived from cereal, starchy tuber and root vegetables, contain small quantities of limiting nutrients per unit of energy, and by themselves are not enough to address the problem of 'hidden hunger' or micronutrients deficiency (Stephenson et al., 2010; Tontisirin et al., 2002). Increasing consumption of micronutrient-dense foods (such as a diversity of fruit, pulses, vegetables and some animal source foods) seen as a practical, costeffective and sustainable way to improve nutrient quality and diets (Johns and Sthapit, 2004). Evidently Vinceti et al. (2013) reported that for supplementation and fortification, locally available and easily accessible, underused complementary foods including wild edible fruit species are affordable and potentially more acceptable than other options. 
Phytic acid is one of anti-nutrient produced by plants for their own defense against herbivorous, insects, pathogens or adverse growing conditions (Herbourne, 1989). Despite this, plnt based food containing phytic acid chelates metal ions, especially zinc, iron, and calcium (Egli et al., 2004), forming insoluble complexes in the gastrointestinal tract that cannot be digested or absorbed in humans because of the absence of intestinal phytase enzymes (Iqbal, 1994). Phytate also complexes endogenously secreted minerals such as zinc (Sandström, 1997) and calcium (Morris and Ellis, 1985) making them unavailable for reabsorption into the body. However, it is noteworthy that myo-inositol phosphates with less than five phosphate groups (i.e., IP-1 to IP-4) do not have a negative effect on zinc absorption (Lönnerdal et al., 1989) whereas myo-inositol phosphates with less than three phosphate groups do not inhibit iron absorption (Sandberg et al., 1999).

The groups most vulnerable to micronutrient deficiencies are pregnant women, lactating women and young children, mainly because they have a relatively greater need for vitamins and minerals and are more susceptible to the harmful consequences of deficiencies. Micronutrient deficiencies increase the general risk of infectious illness and of dying from diarrhoea, measles, malaria and pneumonia. These conditions are among the 10 leading causes of disease in the world today (WHO, 2001b). To reverse such kind of health problem, the study aims to explore locally available underutilized food sources to see its potential for combating a "hidden hunger" after checking its anti-nutritional factor for maximum utilization.

\section{Methods}

\subsection{Study Area Description}

The study undertaken in Temcha Watershed (TW) found in Machakel and Dembecha Districts along the Abay River basin. The river originates from the south-west direction of Choke Mountain and drains in to Abay River after the slope. The watershed targeted for the study is delineated by using Arc GIS 10 software. The watershed lies in between $10^{0} 23^{\prime}$ to $10^{0} 41^{\prime} \mathrm{N}$ latitude and $37^{0} 16^{\prime}$ to $37^{0} 45^{\prime} \mathrm{E}$ longitude which constitutes 73, 054 hectares of land. Administratively, the study area falls in Dembecha District (Western Gojjam) and Machakel District (Eastern Gojjam) in Amhara Regional State (Figure 1). Temcha Watershed is fully covers 10 of the 24 kebeles (sub district) and partially four additional kebeles in Machakel District. It also covers eight of 29 Kebeles and partially five additional kebeles in Dembecha District. Temcha River naturally divded Dembecha District from Machakel District.

\subsection{Data collection methods}

\subsubsection{Site and participant selection}

This study on wild edible plants was conducted from purposely-selected six kebeles with the participation 374 informant. The total number of informants who participated in this study was determined by using 
the formula developed by Cochran (1977).

$$
\mathrm{n}=\frac{\mathrm{N}}{1+\mathrm{N} \mathrm{e}^{2}}
$$

Where $\mathrm{n}=$ sample size $\mathrm{N}=$ population, and $\mathrm{e}=$ sampling error (precision level $=0.05)$. By using all the above information, 374 households were selected sytematically and interviewed.

\subsubsection{Ethnobotanical data and Wild edible plants collection}

Prior to undertaking dietary nutrient analysis on food samples from wild edible fruits, WEFs species were collected through interviews and field observations as described by Martin (1995) and Cotton (1996).Voucher specimens were collected and identified using Flora of Ethiopia and Eritrea. The identified plants were stored at National Herbarium Addis Ababa University.

\subsubsection{Plant part collection for analysis}

\subsubsection{Plant source}

The wild edible fruits were collected from TW after written and oral consent were received from the Districts and sub districts at which the watershed is located and the local people or community that manages the watershed respectively. All the fruits were collected from the wild. Plant specimens were collected and identified using Flora of Ethiopia and Eritrea. The identification process was confirmed by Sebsebe Demissew, the curator of the Herbarium and a Professor of Plant Systematics and Biodiversity in Addis Ababa University. Eventually, the voucher specimens deposited at National Herbarium found in Addis Ababa University.

\subsubsection{Pant part collection}

The edible plant parts, fruits, were collected after the ripening stage (from January 2016 - July 2016) from different forest patches along TW. Healthy and disease free fruit samples were collected in plastic bags and were allowed to dry under shade so as to prevent the decomposition of the chemical compounds present in them. All the dried materials were powdered in blander for further study following standard protocols. Each of the dried food samples ground in to fine powder partly using pestle and mortar and F2102 micro plant grinding machine to fine particles and sieved through a mesh sieve of $1 \mathrm{~mm}$. All dried sub samples were pooled together and the pulverized materials stored in umber (normally dark yellowishbrown in color to protect light not to oxidize the sample) bottles and taken to the Food Science and Nutrition Laboratory, Addis Ababa University for detailed analysis.

\subsection{Data analysis methods}

\subsubsection{Wild edible fruit selection for analysis}


All of the listed use values (UV) was calculated using the formula developed by Phillips and Gentry (1993) after grouped in to different use categories adapted from the classification method proposed by Cook (1995) into the following use categories as per the economic botany data collection standard. These are Fodder (Including animal feed and honeybee forage); Medicines (Including human and veterinary medicines); Food, including beverages; Materials, including handicrafts, dyes, construction; materials, roof thatch, hygienic substances, and toys; Energy (Charcoal and fire wood); Environmental uses (including erosion control, shade/shelter, soil improvers, ornamentals, hedges).

\subsubsection{Determination of calcium (Ca), zinc ( $\mathrm{Zn})$ and iron ( $\mathrm{Fe})$}

The analysis of Ca, Zn, and Fe was done based on the official methods of 999.11 of AOAC (2005). Atomic absorption spectrophotometer (AAS) was used to determine the concentration of the analyzed micronutrient.

The content of each mineral was calculated using the following formula:-

Metal content $\left(\frac{\mathrm{mg}}{100 \mathrm{gm}}\right)=\frac{(\mathrm{Cs}-\mathrm{Cb}) * \mathrm{~V}}{10 \mathrm{xW}}$

Where: Cs: Concentration of sample in ppm, Cb: Concentration of blank in ppm, V: Volume (ml) of extract, W: Weight $(\mathrm{g})$ of samples

\subsubsection{Determination of Phytate}

The phytate contents of fruit flour sample from selected WEF species was determined according to the method stipulated by Wheeler and Ferrel (1971).

The following formula was used to calculate the phytic acid content of the samples.

Phytic acid $\left(\frac{\mu g}{100 g m}\right)=\frac{[(\text { As }-A b)-[\text { Intercept }] 10}{\text { Slope } * w * 3}$

Where: As = sample absorbance, $\mathrm{Ab}=$ blank absorbance, $\mathrm{W}=$ weight of sample

\subsubsection{Determination of molar ratio of phytae / mineral}

The mole of phytate and minerals was determined by dividing the weight of phytate and minerals with its atomic weight (phytate: $660 \mathrm{~g} / \mathrm{mol}$; Ca: $40 \mathrm{~g} / \mathrm{mol}$; Fe: $56 \mathrm{~g} / \mathrm{mol} ; \mathrm{Zn}: 65 \mathrm{~g} / \mathrm{mol}$ ). The molar ratio between phytate and mineral was obtained after dividing the mole of phytate with the mole of minerals (Morris and Ellis, 1989).

\section{Results}




\subsection{Complete list of WEFs and season of fruit ripening period and exact date of collection}

A total of 18 wild edible plants were collected from the three catchments of the watershed (Table 1)

\subsection{Mineral contents (micro nutrient contents) (Zn, Fe and Ca) of WEFs}

Of the micronutrient analyzed, calcium content is the most abundant mineral followed by iron and zinc in all WEFs (Table 2).

\subsubsection{Iron content}

Iron which is commonly deficient in many diets is abundant in this wild edible fruits and the dietary iron content was determined based on the concentration of the standard iron regression curve $\left(R^{2}=9998\right)$ (Figure 2). The concentration of iron varied within the range of $5.84 \mathrm{mg} / 100 \mathrm{~g}$ for Gardenia ternifolia and $148.93 \mathrm{mg} / 100 \mathrm{~g}$ for Cordia africana. Some of the top iron containing WEFs are Cordia africana (148.93 \pm 0.21 ), Ficus vasta ( $45.34 \pm 0.06$ ), Rhus glutinosa ( $35.50 \pm 0.37)$, Syzygium guineense ( $29.88 \pm$ $0.21)$ and Ritchiea albersii $(25.83 \pm 0.75)$.

\subsubsection{Calcium content}

The concentration of calcium from the extracted wild edible fruits is determined from the standard calcium regression curve $\left(\mathrm{R}^{2}=9994\right)$ (Figure 3$)$. The range of calcium in the different plants under study is between $(1280.77 \mathrm{mg} / 100 \mathrm{~g})$ for Ficus sycomorus and $(53.25 \mathrm{mg} / 100 \mathrm{~g})$ for Ximenia americana. The 8 top wild edible fruits that contain large amount of calcium in the edible parts are Ficus sycomorus (1280.77 \pm 22.98$)$, Ficus vasta $(972.98 \pm 12.53)$, Ficus sur (659.33 \pm 5.15$)$, Cordia africana (573.20 \pm 4.09), Rhus glutinosa (565.13 \pm 9.84$)$, Rubus steudneri (558.60 \pm 4.63$)$, Rubus apetalus (538.65 \pm 0.00 ) and Rosa abyssinica (483.12 \pm 2.69$)$ (Table 2).

\subsubsection{Zinc content}

Zinc contents of selected WEFs were analyzed from the concentration of the standard zinc regression curve $\left(R^{2}=9979\right)$ (Figure 4). The concentration of zinc value is ranging from $(0.66 \pm 0.02)$ for Syzygium guineense and ( $88.89 \pm 0.42 \mathrm{mg} / 100 \mathrm{~g})$ for Rhus glutinosa. The top most zinc containing WEFs are Rhus glutinosa (88.89 \pm 0.42$)$, Embelia schimperi (45.12 \pm 1.11$)$, Phoenix reclinata (27.71 \pm 0.49$)$, Ritchiea albersii (27.01 \pm 0.13$)$ and Cordia africana (17.27 \pm 0.54$)$ (Table 2).

\subsection{Phytate contents and Molar ratios of Phytate and micronutrient analyzed in this study}

\subsubsection{Phytate contents}

The analyzed wild edible fruits contain different amount of phytate. This content is determined from the regression equation of calibration curve $\left(R^{2}=0.9823\right.$ and $\left.R^{2}=0.9943\right)$ (Figure 5). Its value is in between $6.9 \pm 0.00 \mathrm{mg} / 100 \mathrm{~g}$ for Gardenia ternifolia to $51.4 \pm 0.041 \mathrm{mg} / 100 \mathrm{~g}$ for Clausena anisata. The top seven wild edible fruits that contain high phytate are Clausena anisata (51.4 \pm 0.04$)$, Ficus vasta (50.7 \pm 
04), Capparis tomentosa (49.8 \pm 0.00$)$, Ficus sur ( $48.6 \pm 0.00)$, Ritchiea albersii ( $45.6 \pm 0.00)$, Ehretia cymosa $(40.9 \pm 0.00)$ and Cordia africana $(40.7 \pm 0.46)$ (Table 3$)$.

\section{3.2 Molar ratios of Phytate and micronutrient analyzed in this study}

Molar ratios of [phytate]: [iron], [phytate]: [zinc] and [phytate]: [calcium] provides an estimate of the relative bioavailability of these minerals in the wild edible fruits. The results showed that molar ratio of phytate with calcium ranged in between $0.001 \pm 0.00$ for Gardenia ternifolia to $0.044 \pm 0.00$ for Ximenia americana. Molar ratio of phytate with iron ranged in between $0.023 \pm 0.00$ for Cordia africana to $0.478 \pm$ 0.01 for Ximenia americana and molar ratio of phytate with zinc ranged in between $0.023 \pm 0.00$ for Cordia africana to $4.137 \pm 0.00$ for Ficus sur.

\section{Discussion}

\subsection{Mineral contents (micro nutrient contents) (Fe, Ca and $\mathrm{Zn}$,) of WEFs}

Some WEFs had significant level of micronutrients and identified as promising species for promotion as backyard planting especially farming systems suffering from crop loss, food shortage and chronic malnutrition.

\subsubsection{Iron}

The recommended nutrient intake for iron is varying depending up on the type of human social group (children, males, females post-menopausal and lactating), ages and mean body weight (FAO / WHO, 2001). According to FAO/WHO (2001), children up to 10 years required $11.6-17.8 \mathrm{mg} /$ day. Whereas males whose ages range from 11- 18 years require $27.4-37.6 \mathrm{mg} /$ day, Females with similar age require $28-65.4 \mathrm{mg} /$ day. Cordia africana (148.93 \pm 0.21$)$, Ficus vasta (45.34 \pm 0.06$)$, Rhus glutinosa (35.50 \pm $0.37)$ and Syzygium guineense $(29.88 \pm 0.10)$ provides optimum amount of iron for both males and females whose age is in between 11 and 18 (FAO / WHO, 2001). Whereas, a combination of the rest of WEFs provides optimum amount of iron for both males and females whose age is in between 11 and 18 . Almost all WEFs either alone or a combination of them provides optimum amount of iron for children up to 10 years. From data taken from Ethiopian food composition table (EHNRI, 1997), Cultivated cereal crops Eleusine coracana) that gives $37.9 \mathrm{mg} / 100 \mathrm{~g}$ and Teff (Eragrostis tef) flour which has highest iron content of $150 \mathrm{mg} / 100 \mathrm{~g}$.

\subsubsection{Calcium}

In this study, the three plants found in the Moraceae family contain a large amount of calcium. If a person aged between 10 and 18 years eats at $100 \mathrm{~g}$ dry weight basis either of these two plants can meet the daily needs of calcium (1300 mg / $100 \mathrm{~g}$ ) (FAO / WHO, 2001). Furthermore, combination of Ficus sycomorus and either of all wild edible fruits studied, when it has been eaten in $100 \mathrm{~g}$ dry weight basis, it satisfies the daily needs of calcium of male and female individuals in the range of 10-18 age. 
The World Health Organization recommended supplementations of 1.5 - $2 \mathrm{~g}(1500 \mathrm{mg}-2000 \mathrm{mg})$ of calcium daily for all pregnant women in populations with usual calcium intake averaging less than 900 $\mathrm{mg} /$ day to prevent pre-eclampsia / eclampsia that is responsible for an estimated $16 \%$ of the maternal mortality (Khan et al., 2006). The national survey conducted by the Ethiopian Public Health Institute (ENFCS, 2013) indicated that the average calcium intake by the Ethiopian women is about $317.32 \mathrm{mg} /$ day. This is far below the estimated average need for women (1300 mg / day) of 10 - 18 years and 1000 $\mathrm{mg} /$ day for above 19 years. Therefore, WEFs had a lot of contribution to provide reasonable amount of calcium for the community. The good news in relation with calcium in the study area is, people harvest Ficus surfruit and sold the dried fruit in the local market. These largely supplement cereal based diets in the study area to get the daily-recommended intake of calcium.

\subsubsection{Zinc}

The effect of zinc on iron absorption observed when the zinc: iron ratio exceeded 3:1 in a given meal (Davidsson et al., 1995). Whereas when the zinc : iron ratio increased to $5: 1$, there was a marked negative effect upon iron absorption (56\% decline). Among the analyzed data, eating Embelia schimperi fruit might affect absorption of zinc because the zinc: iron ratio of Embelia shimperi diet is 7:1. The rest of the wild edible fruits will not have such kind of problems because the ratio is within the normal range. Zinc is a cofactor for over 100 enzymes, involved in modulating enzyme activity or are an integral part of enzyme prosthetic groups (Shenkin, 2006). Therefore, the different amount of zinc from these wild edible fruit species contributes a lot to the study area community and the knowledge can be extended to similar areas of Ethiopia.

\subsection{Role of Phytic acid content and bioavailability of calcium, iron and zinc in wild edible plants}

The available literature indicates that Phytate might be exerting its inhibitory effect on the bioavailability of calcium, iron and zinc from the diet that had molar ratios above the cut-off points (Liener et al., 1980, Larsson et al., 1996). Whether or not high levels of consumption of phytate-containing foods will result in mineral deficiency will depend on what else is being consumed. The phytate contents of WEPs in this study resulted in the range of $6.93 \pm 0.00$ for Gardenia ternifolia to $51.38 \pm 0.041$ for Clausena anisata. The recommended critical values and the results are as follows: The molar ratio of phytate with zinc in the analyzed WEFs varied from 0.03 for Embelia schimperi and 4.12 for Ficus sur. [phytate]: [zinc] $\geq 15$ (Morris and Ellis., 1985) for zinc. It is lower than the critical molar ratios of Phytate: Zinc, which indicates the high bioavailability of zinc consumed from WEFs.

Molar ratio of phytate with iron varied from 0.02 for Cordia africana and 0.48 for Ximenia americana but [phytate]: [iron] $\geq 1$ (Hallberg et al., 1989) for iron. This is also below the range indicating the high bioavailability of iron. Molar ratio of phytate with calcium is in the range of 0.04 for Ximenia americana and below 0.01 in most WEFs but [phytate]: [calcium] $\geq 0.24$ (Morris and Ellis., 1985) for calcium. Molar ratio of phytate with calcium is in the range of 0.04 for Ximenia americana and below 0.01 in most WEF and this is also below the range indicating the high bioavailability of calcium. 
The ([Ca][Phy]/ [Zn] molar ratios of the analyzed edible fruits varied from 0.18 for Embelia schimperi to 68.06 for Ficus sur. [phytate] $\times$ [calcium] / [zinc] $>200$ for the combined effect of phytate and calcium on zinc (Gibson et al., 1991). These values are lower than the critical molar ratios of [Ca][phytate]/ [Zn], which indicates high bioavailability of zinc in all wild edible fruits tested. Therefore, the phytate concentrations of WEFs do not have a negative impact on the bioavailability of calcium, iron and zinc from WEFs diet. This result supports very low levels of phytate contents of roots and tubers and most leafy vegetables and fruits than cereals as reported by Reddy (2002).

\section{Conclusions}

The nutritional values of WEFs had a lot of contribution to meet the daily-recommended allowance of different micronutrients like calcium, iron and zinc for a certain age group in the community. Cordia africana and Phoenix reclinata collected from the lower and middle catchments and Ritchiea albersii and Rhus glutinosa and Rubus apetalus were distributed throughout the watershed provided a reasonable amount of calcium, iron and zinc contents to the community. Ficus sur and Rubus steudneri were collected from the three catchments in the watershed while Ficus sycomorus was restricted to the lower catchment were claimed to be the best source of calcium. All these provided information on their usefulness both from the community consensus results and the dietary test results regarding their potentials for nutritional and medicinal applications.

\section{Abbreviations}

\begin{tabular}{ll} 
WEFs & Wild Edible Fruits \\
\hline WHO & World Health Organization \\
\hline TW & Temcha Watershed \\
\hline UVs & Use Values \\
\hline FAO & Food and Agricultural Organization \\
\hline AOAC & Association of Official Analytical Chemists \\
\hline EHNRI & Ethiopian Health and Nutrition Research Institute
\end{tabular}

\section{Declarations}

\section{Acknowledgement}

The author would like to acknowledge Debre Markos University that guaranteed me the study leave, monthly salary and Ministry of Education and Addis Ababa University (Department of Plant Biology and Biodiversity Management) for accepting me as a PhD student.

\section{Authors' Contributions}


'HR', ZA' and 'SD' have designed the proposal, data collection, data analysis, interpretation and later developed this manuscript. 'AZ' has supervised the micronutrient analysis and phytic acid determination during laboratory experiment. Both authors read and approved the final manuscript.

\section{Funding}

Orkssove Foundation and Rufford Small Grants were provided a small grants used for domestic training in GIS to do my study map and modest fund to do Nutritional Analysis respectively.

\section{Ethics approval and consent to participate}

Prior to plant sample collection, a formal letter request of cooperation was submitted to the Machkel District and Dembecha District where Temcha Watershed is administered and the administrative offices has approved the request and give me a letter of acceptance. Accordingly, the necessary oral consents were obtained from each informant who participated during ethnobotanical data collection of the wild edible fruits after explaining the objectives of the work.

\section{Availability of data and materials}

The data used and analyzed in this study are available from the corresponding author on reasonable request.

\section{Consent for publication}

This is not applicable, since any photographs or videos were not taken.

\section{Competing interests}

The authors declare that they have no competing interests.

\section{References}

AOAC (Association of Official Analytical Chemists). Official Method of analysis, 17th edition. AOAC, Gaithersberg; 2005.

Cochran WG. Sampling Techniques (3rd ed.). Jahn Wiley and Sons, New York; 1977.

Cook FRM. Economic Botany Data Collection Standard. Kew Botanical Gardens, UK; 1995.

Cotton CM. Ethnobotany: Principles and Applications. John Wiley and Sons Ltd. Chichister, England; 1996.

Davidsson L, Almgren A, Sandstrom B, Hurrell RF. Zinc absorption in adult humans: the effect of iron fortification. British Journal of Nutrition 1995; 74, 417-25 
Egli I, Davidsson L, Zeder C, Walczyk T, Hurrell R. Dephytinization of a Complementary food based on wheat and soy increases zinc, but not copper, apparent absorption in adults. Journal of Nutrition 2004;134,1077-80.

ENFCS. Ethiopia National Food Consumption Survey. Ethiopian Public Health Institute Addis Ababa, Ethiopia; 2013.

EHNRI (Ethiopian Health and Nutrition Research Institute). Food composition Table for use in Ethiopia. Part IV. 1995-1997. Ethiopian Health and nutrition Research Unit/ Food Agriculture organization, Addis Ababa Ethiopia; 1997.

FAO/WHO. FAO/WHO expert consultation on human vitamin and mineral requirements. Bangkok, Thailand; 2001.

Gibson RS, Vanderkooy PDS, Thompson L. Dietary phytate $x$ calcium/zinc millimolar ratios and zinc nutritive in some Ontario preschool children. Biological Trace Element Research 1991; 30, 87-94.

Hallberg L, Brune M, Rosander L. Iron absorption in man: ascorbic acid and dosedependent inhibition by phytate. American Journal of Clinical Nutrition 1989; 49,140-4

Herbourne JB. Biosynthesis and functions of anti-nutritional factors in plants. Aspects of Applied Biology 1989; 19, 21-28.

Iqbal TH, Lewis KO, Cooper BT. Phytase activity in the human and rat small intestine. Gut. 1994; 35, 1233-6.

Johns T, Sthapit BR. Biocultural diversity in the sustainability of developing-country food systems. Food and Nutrition Bulletin 2004; 25,143-155.

Khan KS, Wojdyla D, Say L, Gulmezoglu AM, Van Look PF. WHO analysis of causes of maternal death: a systematic review. The lancet 2006; 367(9516): 1066-1074.

Larsson M, Rosande-Hulthen L, Sandstome B, Sandberg A. Improved iron and zinc absorption from breakfast meals containing malted oats with reduced phytate content. British Journal of Nutrition 1996; $76,677-688$.

Liener IE, Kkade ML. Protease inhibitor. In Liener, I. E. (ed.), Toxic constituents of plants foodstuffs. Academic Press, New York; 1980.

Lönnerdal B, Sandberg A, Sandström B, Kunz C. Inhibitory effects of phytic acid and other inositol phosphates on zinc and calcium absorption in suckling rats. Journal of Nutrition 1989; 119, 211-4

Martin GJ. Ethnobotany: A Methods Manual. Chapman and Hall, London; 1995. 
Morris ER., Ellis R. Usefulness of the dietary phytic acid/zinc molar ratio as an index of zinc bioavailability to rats and humans. Biol Trace Elem Res.1989; 19, 107-17.

Morris ER. Ellis R. Bioavailability of dietary calcium. In Kies C, (ed.), Nutritional Bioavailabilty of Calcium, (pp 63-67). American Chemical Society, Washington DC. 1985. P.63-67.

Phillips O, Gentry AH. The useful plants of Tambopata, Peru: I. Statistical hypotheses with a new quantitative technique. Economic Botany, 1993; 47: 15-32.

Reddy NR. Occurrence, distribution, content and dietary intake of phytate. In Reddy, N.R., \& Sathe, S. K., (eds.), Food phytates. CRC Press, London; 2002.p. 25-30.

Shenkin A. Micronutrients in health and disease. Postgraduate Medical Journal 2006; 82: 559-567.

Sandström B. Bioavailability of zinc. European Journal of Clinical Nutrition 1997; 51(1): 517-519.

Sandberg AS, Brune M, Carlsson NG, Hallberg L, Skoglund E, Rosander-Hulthen L. (). Inositol phosphates with different numbers of phosphate groups influence iron absorption in humans. American Journal of Clinical Nutrition 1999; 70: 240-6.

Stephenson K, Amthor R, Mallowa S, Nungo R, Maziya-Dixon B, Gichuki S, Mbanaso A, Manary, M. Consuming cassava as a staple food places children 2-5 years old at risk for inadequate protein intake, an observational study in Kenya and Nigeria. Nutrition Journal 2010; doi: 10.1186/1475-2891-9-9

Tontisirin K, Nantel G, Bhattacharjee L. Food-based strategies to meet the challenges of micronutrient malnutrition in the developing world. Proceedings of the Nutrition Society 2002; 61: 243-250.

Vinceti B, Termote C, Ickowitz A, Powell B, Kehlenbeck K, Hunter D. The Contribution of Forests and Trees to Sustainable Diets. Sustainability 2013; 5:4797-4824.

Wheeler EL, Ferrel RE. Method for phytic acid determination in wheat and wheat fractions. Western regional research laboratory, Agricultural research service, U.S. Department of agriculture. Albany California; 1971.

WHO. Age standardization of rates: a new who standard. GPE Discussion Paper Series: No.31. EIP/GPE/EBD; $2001 \mathrm{a}$.

WHO. Iron deficiency anaemia assessment, prevention and control: a guide for programme managers WHO/UNICEF/United Nations University. Geneva, (document WHO/NHD/01.3; 2001b.

\section{Tables}

Table 1 Complete list of WEFs collected from TW $(\mathrm{H}=$ habit, $\mathrm{MC}=$ mode of consumption, EDC $=$ Exact date of collection, FRP = Fruit ripening period or calendar) 


\begin{tabular}{|c|c|c|c|c|c|c|c|c|}
\hline No. & Scientific name & Family Name & $\begin{array}{l}\text { Local name } \\
\text { (Amharic) }\end{array}$ & $\mathrm{H}$ & $\begin{array}{l}\text { Parts } \\
\text { used }\end{array}$ & $\mathrm{MC}$ & FRP & EDC \\
\hline 3 & $\begin{array}{l}\text { Capparis } \\
\text { tomentosa }\end{array}$ & Capparaceae & GuMERo & $\mathrm{S}$ & $\begin{array}{l}\text { Ripe } \\
\text { Fruit }\end{array}$ & Raw & June-July & $29 / 08 / 08$ \\
\hline 4 & $\begin{array}{l}\text { Carissa } \\
\text { spinarum }\end{array}$ & Apocynaceae & $\overline{A G A M}$ & $\mathrm{~S}$ & $\begin{array}{l}\text { Ripe } \\
\text { Fruit }\end{array}$ & Raw & March & $28 / 06 / 08$ \\
\hline 5 & Clausena anisata & Fabaceae & Liмich & $\mathrm{S}$ & $\begin{array}{l}\text { Ripe } \\
\text { Fruit }\end{array}$ & Raw & May-June & $29 / 08 / 08$ \\
\hline 6 & Cordia africana & Boraginaceae & WANZA & $\mathrm{T}$ & $\begin{array}{l}\text { Ripe } \\
\text { Fruit }\end{array}$ & Raw & $\begin{array}{l}\text { January - } \\
\text { February }\end{array}$ & $25 / 06 / 08$ \\
\hline 9 & Ehretia cymosa & Boraginaceae & Wulaga & $\mathrm{T}$ & $\begin{array}{l}\text { Ripe } \\
\text { Fruit }\end{array}$ & Raw & March & $29 / 08 / 08$ \\
\hline 10 & $\begin{array}{l}\text { Embelia } \\
\text { schimperi }\end{array}$ & Myrsinaceae & ENKOKO & $\mathrm{S}$ & $\begin{array}{l}\text { Ripe } \\
\text { Fruit }\end{array}$ & Raw & $\begin{array}{l}\text { January- } \\
\text { February }\end{array}$ & $28 / 06 / 08$ \\
\hline 12 & $\begin{array}{l}\text { Eriosema } \\
\text { cordifoliium }\end{array}$ & Fabaceae & ENKERKAFO & $\mathrm{H}$ & $\begin{array}{l}\text { Root } \\
\text { tuber }\end{array}$ & Raw & June-July & \\
\hline 13 & Ficus sur & Moraceae & SHOLLA & $\mathrm{T}$ & $\begin{array}{l}\text { Ripe } \\
\text { Fruit }\end{array}$ & $\begin{array}{l}\text { Raw and } \\
\text { Dried }\end{array}$ & March-April & $25 / 06 / 08$ \\
\hline 14 & Ficus sycomorus & Moraceae & ABUAR & $\mathrm{T}$ & $\begin{array}{l}\text { Ripe } \\
\text { Fruit }\end{array}$ & Raw & April & $7 / 7 / 2007$ \\
\hline 15 & Ficus vasta & Moraceae & WARKA & $\mathrm{T}$ & $\begin{array}{l}\text { Ripe } \\
\text { Fruit }\end{array}$ & Raw & March-April & $6 / 7 / 2008$ \\
\hline 16 & $\begin{array}{l}\text { Gardenia } \\
\text { ternifolia }\end{array}$ & Rubiaceae & GoBIN/GUABILO & $\mathrm{T}$ & $\begin{array}{l}\text { Ripe } \\
\text { Fruit } \\
\end{array}$ & Raw & $\begin{array}{l}\text { February- } \\
\text { March }\end{array}$ & $7 / 7 / 2008$ \\
\hline 23 & $\begin{array}{l}\text { Phoenix } \\
\text { reclinata }\end{array}$ & Arecaceae & CHIFAR & $\mathrm{T}$ & $\begin{array}{l}\text { Ripe } \\
\text { Fruit }\end{array}$ & Raw & May-June & $29 / 08 / 08$ \\
\hline 24 & Rhus glutinosa & Anacardaceae & AsHKamo & $\mathrm{S}$ & $\begin{array}{l}\text { Ripe } \\
\text { Fruit }\end{array}$ & Raw & April-June & $29 / 08 / 08$ \\
\hline 25 & Ritchiea albersii & Capparidaceae & Сномүе & $\mathrm{T}$ & $\begin{array}{l}\text { Ripe } \\
\text { Fruit }\end{array}$ & Raw & May-June & $29 / 08 / 08$ \\
\hline 26 & Rosa abyssinica & Rosaceae & KEGA & $\mathrm{S}$ & $\begin{array}{l}\text { Ripe } \\
\text { Fruit } \\
\end{array}$ & Raw & $\begin{array}{l}\text { February- } \\
\text { March }\end{array}$ & $13 / 07 / 08$ \\
\hline 27 & Rubus apetalus & Rosaceae & YEDEGA ENJOR & $\mathrm{S}$ & $\begin{array}{l}\text { Ripe } \\
\text { Fruit } \\
\end{array}$ & Raw & $\begin{array}{l}\text { February- } \\
\text { March }\end{array}$ & $6 / 7 / 2008$ \\
\hline 28 & Rubus steudneri & Rosaceae & YEWOF ENJORY & $\mathrm{S}$ & $\begin{array}{l}\text { Ripe } \\
\text { Fruit }\end{array}$ & Raw & $\begin{array}{l}\text { February- } \\
\text { March }\end{array}$ & $6 / 7 / 2008$ \\
\hline 32 & $\begin{array}{l}\text { Syzygium } \\
\text { guineense }\end{array}$ & Myrtaceae & BEDEsSA & $\mathrm{T}$ & $\begin{array}{l}\text { Ripe } \\
\text { Fruit }\end{array}$ & Raw & May- June & $29 / 08 / 08$ \\
\hline 34 & $\begin{array}{l}\text { Ximenia } \\
\text { americana }\end{array}$ & Olacaceae & ENKOY & $\mathrm{S}$ & $\begin{array}{l}\text { Ripe } \\
\text { Fruit }\end{array}$ & Raw & May-June & \\
\hline
\end{tabular}

Table2 Mineral contents of selected WEFs in TW 


\begin{tabular}{llll}
\hline List of plants & Zink $(\mathrm{mg} / 100 \mathrm{~g})$ & $\mathrm{Fe}(\mathrm{mg} / 100 \mathrm{~g})$ & $\mathrm{Ca}(\mathrm{mg} / 100 \mathrm{~g})$ \\
\hline Capparis tomentosa & $2.34 \pm 0.05$ & $14.68 \pm 0.05$ & $98.41 \pm 0.08$ \\
Carissa spinarum & $8.86 \pm 0.07$ & $12.59 \pm 0.34$ & $254.22 \pm 0.20$ \\
Clausena anisata & $2.50 \pm 0.05$ & $13.63 \pm 0.07$ & $419.36 \pm 3.02$ \\
Cordia africana & $17.27 \pm 0.54$ & $148.93 \pm 0.21$ & $573.21 \pm 4.09$ \\
Ehretia cymosa & $4.30 \pm 0.06$ & $16.19 \pm 0.41$ & $293.94 \pm 1.61$ \\
Embelia schimperi & $45.12 \pm 1.11$ & $6.22 \pm 0.11$ & $250.38 \pm 0.80$ \\
Ficus sur & $1.16 \pm 0.00$ & $9.18 \pm 0.11$ & $659.33 \pm 5.15$ \\
Ficus sycomorus & $5.65 \pm 0.06$ & $21.46 \pm 0.28$ & $1280.77 \pm 22.98$ \\
Ficus vasta & $2.27 \pm 0.02$ & $45.34 \pm 0.06$ & $972.98 \pm 12.54$ \\
Gardenia ternifolia & $4.01 \pm 0.12$ & $5.84 \pm 0.00$ & $438.84 \pm 6.17$ \\
Phoenix reclinata & $27.71 \pm 0.49$ & $17.24 \pm 0.39$ & $156.11 \pm 0.49$ \\
Rhus glutinosa & $88.89 \pm 0.42$ & $35.50 \pm 0.37$ & $565.14 \pm 9.85$ \\
Ritchiea albersii & $27.01 \pm 0.13$ & $25.83 \pm 0.75$ & $235.43 \pm 3.02$ \\
Rosa abyssinica & $8.31 \pm 0.13$ & $7.75 \pm 0.10$ & $483.12 \pm 2.69$ \\
Rubus apetalus & $2.69 \pm 0.00$ & $14.81 \pm 0.91$ & $538.65 \pm 0.00$ \\
Rubus steudneri & $2.71 \pm 0.01$ & $6.86 \pm 0.04$ & $558.60 \pm 4.63$ \\
Syzygium guineense & $0.66 \pm 0.02$ & $29.88 \pm 0.10$ & $433.33 \pm 0.98$ \\
Ximenia americana & $1.53 \pm 0.00$ & $6.77 \pm 0.21$ & $53.25 \pm 0.45$ \\
\hline
\end{tabular}

Table3 Phytic content, molar ratio of phytic acid and calcium with zinc and molar ratio of phytate with micronutrients (calcium, iron and zinc) 


\begin{tabular}{|c|c|c|c|c|c|}
\hline $\begin{array}{l}\text { List of } \\
\text { plants }\end{array}$ & $\begin{array}{l}\text { Phytic } \\
\text { acid } \mu g \\
\text { /g }\end{array}$ & $\begin{array}{l}\text { Molar ratio of } \\
{[\text { Phytate }]} \\
{[\text { Calcium }] /[\text { Zinc }]}\end{array}$ & $\begin{array}{lr}\text { Molar ratio of } \\
\text { phytate } & \text { with } \\
\text { calcium } & \end{array}$ & $\begin{array}{l}\text { Molar ratio of } \\
\text { phytate with iron }\end{array}$ & $\begin{array}{l}\text { Molar ratio of } \\
\text { phytate with zinc }\end{array}$ \\
\hline $\begin{array}{l}\text { Capparis } \\
\text { tomentosa }\end{array}$ & $\begin{array}{l}498.46 \pm \\
0.00\end{array}$ & $5.15 \pm 0.11$ & $0.031 \pm 0.00$ & $0.288 \pm 0.00$ & $2.105 \pm 0.05$ \\
\hline $\begin{array}{l}\text { Carissa } \\
\text { spinarum }\end{array}$ & $\begin{array}{l}336.77 \pm \\
0.00\end{array}$ & $2.38 \pm 0.01$ & $0.008 \pm 0.00$ & $0.227 \pm 0.00$ & $0.375 \pm 0.00$ \\
\hline $\begin{array}{l}\text { Clausena } \\
\text { anisata }\end{array}$ & $\begin{array}{l}513.75 \pm \\
0.041\end{array}$ & $21.24 \pm 0.63$ & $0.007 \pm 0.00$ & $0.320 \pm 0.00$ & $2.023 \pm 0.05$ \\
\hline $\begin{array}{l}\text { Cordia } \\
\text { africana }\end{array}$ & $\begin{array}{l}406.77 \pm \\
0.46\end{array}$ & $3.32 \pm 0.12$ & $0.004 \pm 0.00$ & $0.023 \pm 0.00$ & $0.232 \pm 0.00$ \\
\hline $\begin{array}{l}\text { Ehretia } \\
\text { cymosa }\end{array}$ & $\begin{array}{l}409.09 \pm \\
0.00\end{array}$ & $6.88 \pm 0.13$ & $0.008 \pm 0.00$ & $0.214 \pm 0.00$ & $0.938 \pm 0.01$ \\
\hline $\begin{array}{l}\text { Embelia } \\
\text { schimperi }\end{array}$ & $\begin{array}{l}136.13 \pm \\
0.00\end{array}$ & $0.18 \pm 00$ & $0.003 \pm 0.00$ & $0.186 \pm 0.00$ & $0.029 \pm 0.00$ \\
\hline Ficus sur & $\begin{array}{l}486.35 \pm \\
0.00\end{array}$ & $68.06 \pm 0.34$ & $0.004 \pm 0.00$ & $0.450 \pm 0.00$ & $4.137 \pm 0.01$ \\
\hline $\begin{array}{l}\text { Ficus } \\
\text { sycomorus }\end{array}$ & $\begin{array}{l}391.61 \pm \\
0.00\end{array}$ & $21.83 \pm 0.15$ & $0.002 \pm 0.00$ & $0.155 \pm 0.00$ & $0.683 \pm 0.00$ \\
\hline Ficus vasta & $\begin{array}{l}507.15 \pm \\
044\end{array}$ & $53.49 \pm 1.3$ & $0.003 \pm 0.00$ & $0.095 \pm 0.00$ & $2.204 \pm 0.03$ \\
\hline $\begin{array}{l}\text { Gardenia } \\
\text { ternifolia }\end{array}$ & $\begin{array}{l}69.27 \pm \\
0.00\end{array}$ & $1.87 \pm 0.03$ & $0.001 \pm 0.00$ & $0.101 \pm 0.00$ & $0.171 \pm 0.00$ \\
\hline $\begin{array}{l}\text { Phoenix } \\
\text { reclinata }\end{array}$ & $\begin{array}{l}358.06 \pm \\
0.00\end{array}$ & $0.5 \pm 0.01$ & $0.014 \pm 0.00$ & $0.176 \pm 0.00$ & $0.127 \pm 0.00$ \\
\hline $\begin{array}{l}\text { Rhus } \\
\text { glutinosa }\end{array}$ & $\begin{array}{l}316.64 \pm \\
0.00\end{array}$ & $0.49 \pm 0.01$ & $0.003 \pm 0.00$ & $0.076 \pm 0.00$ & $0.035 \pm 0.00$ \\
\hline $\begin{array}{l}\text { Ritchiea } \\
\text { albersii }\end{array}$ & $\begin{array}{l}455.77 \pm \\
0.00\end{array}$ & $0.98 \pm 0.01$ & $0.012 \pm 0.00$ & $0.150 \pm 0.00$ & $0.166 \pm 0.00$ \\
\hline $\begin{array}{l}\text { Rosa } \\
\text { abyssinica }\end{array}$ & $\begin{array}{l}371.94 \pm \\
0.46\end{array}$ & $5.32 \pm 0.1$ & $0.005 \pm 0.00$ & $0.407 \pm 0.00$ & $0.441 \pm 0.00$ \\
\hline $\begin{array}{l}\text { Rubus } \\
\text { apetalus }\end{array}$ & $\begin{array}{l}342.90 \pm \\
0.47\end{array}$ & $16.89 \pm 0.03$ & $0.004 \pm 0.00$ & $0.197 \pm 0.01$ & $1.257 \pm 0.00$ \\
\hline $\begin{array}{l}\text { Rubus } \\
\text { steudneri }\end{array}$ & $\begin{array}{l}299.35 \pm \\
0.00\end{array}$ & $15.16 \pm 0.18$ & $0.003 \pm 0.00$ & $0.370 \pm 0.00$ & $1.088 \pm 0.00$ \\
\hline $\begin{array}{l}\text { Syzygium } \\
\text { guineense }\end{array}$ & $\begin{array}{l}107.86 \pm \\
0.00\end{array}$ & $17.31 \pm 0.54$ & $0.002 \pm 0.00$ & $0.031 \pm 0.00$ & $1.601 \pm 0.05$ \\
\hline $\begin{array}{l}\text { Ximenia } \\
\text { americana }\end{array}$ & $\begin{array}{l}381.61 \pm \\
0.46\end{array}$ & $3.27 \pm 0.03$ & $0.044 \pm 0.00$ & $0.478 \pm 0.01$ & $2.460 \pm 0.00$ \\
\hline
\end{tabular}


Figures

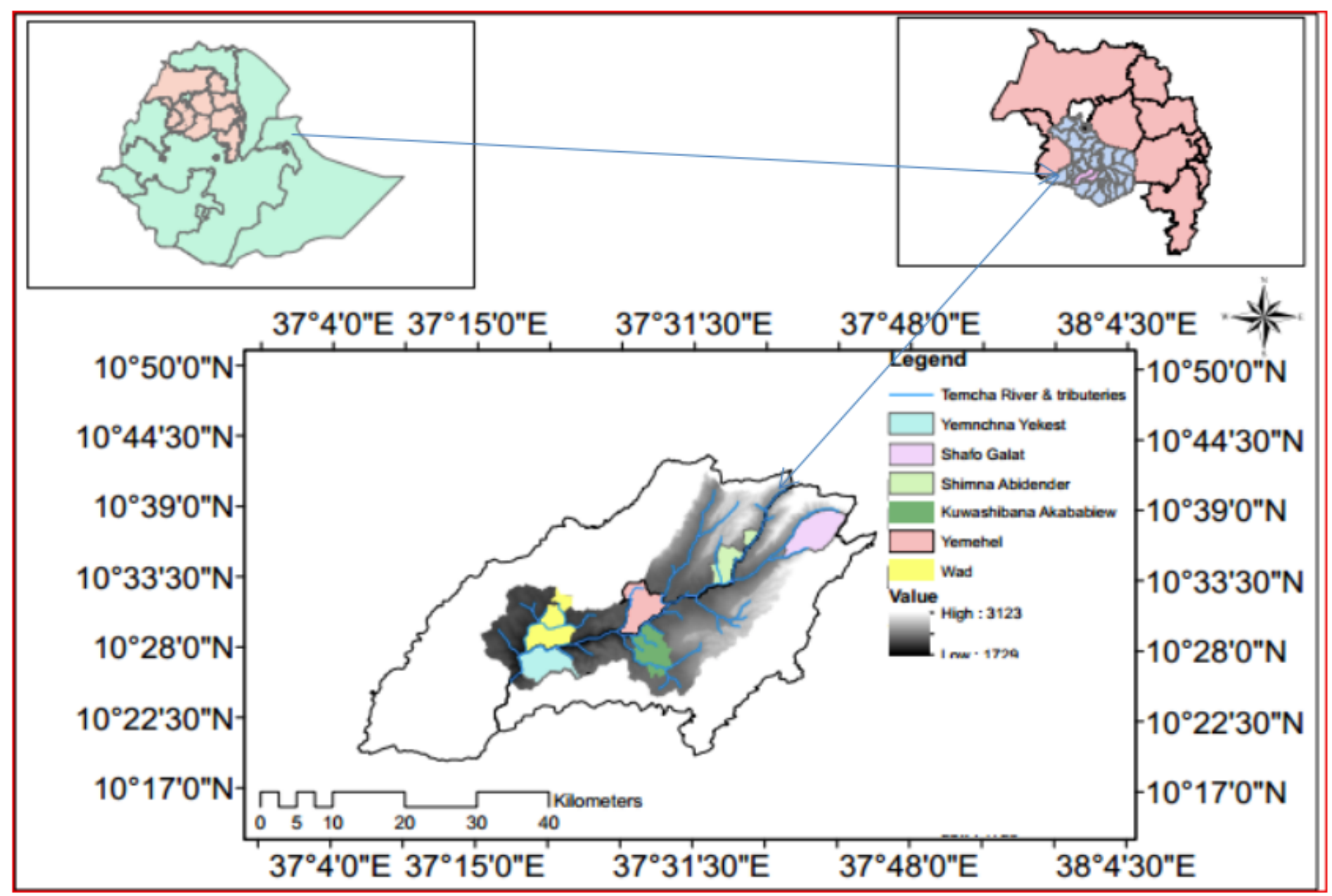

Figure 1

Map of Ethiopia showing regional states, districts, Temcha Watershed and sampled kebeles (Developed using Arc GIS 10). (Source of the shape file: accessed from Ethiopian Mapping Agency) 


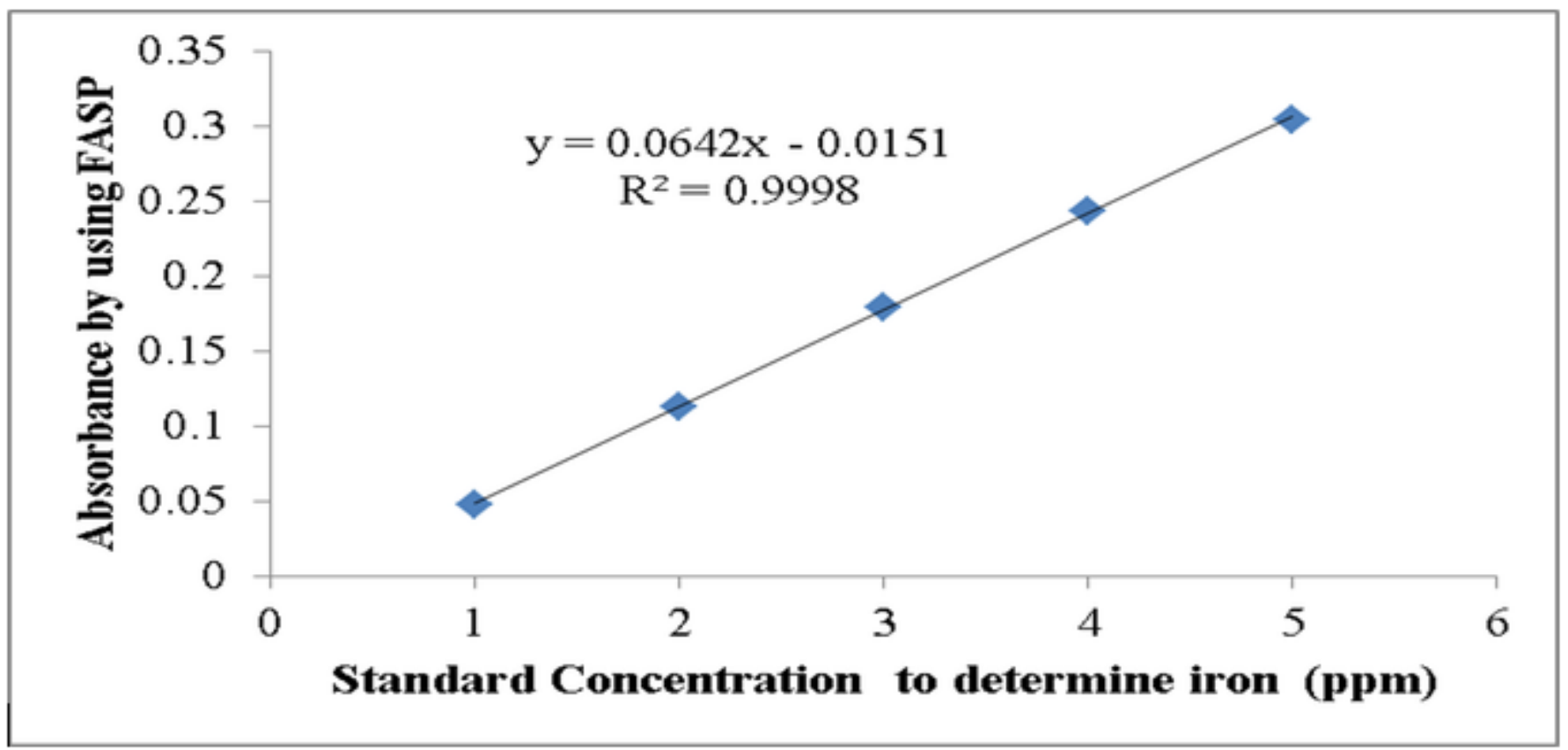

Figure 2

Standard calibration curves to determine iron

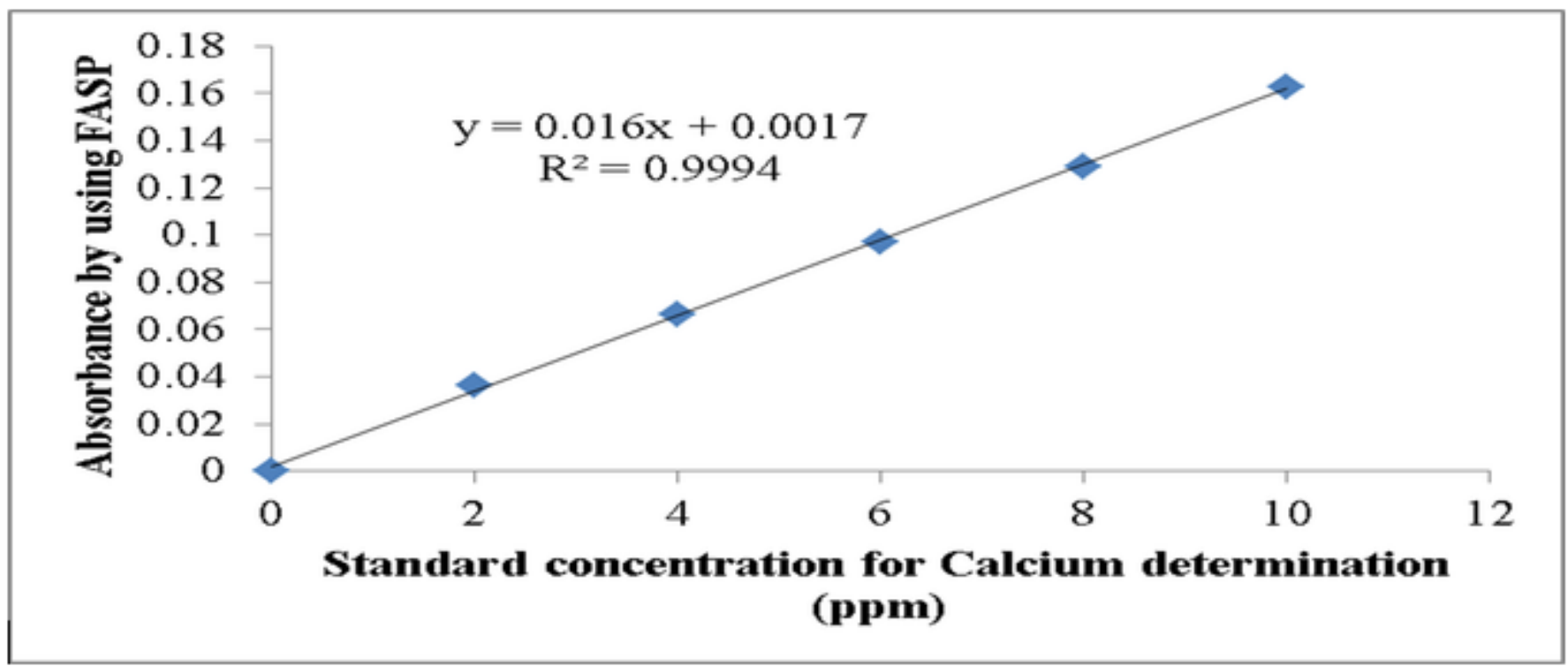

Figure 3

Standard calibration curve to determine Calcium 


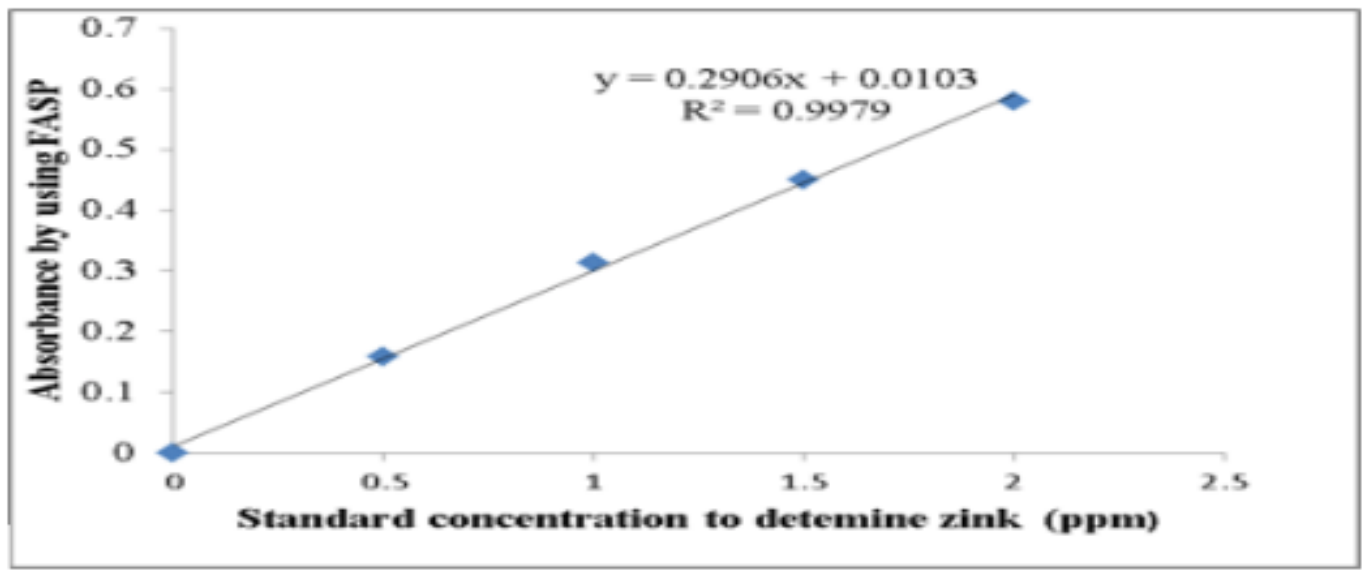

Figure 4

Standard calibration curve to determine Zinc
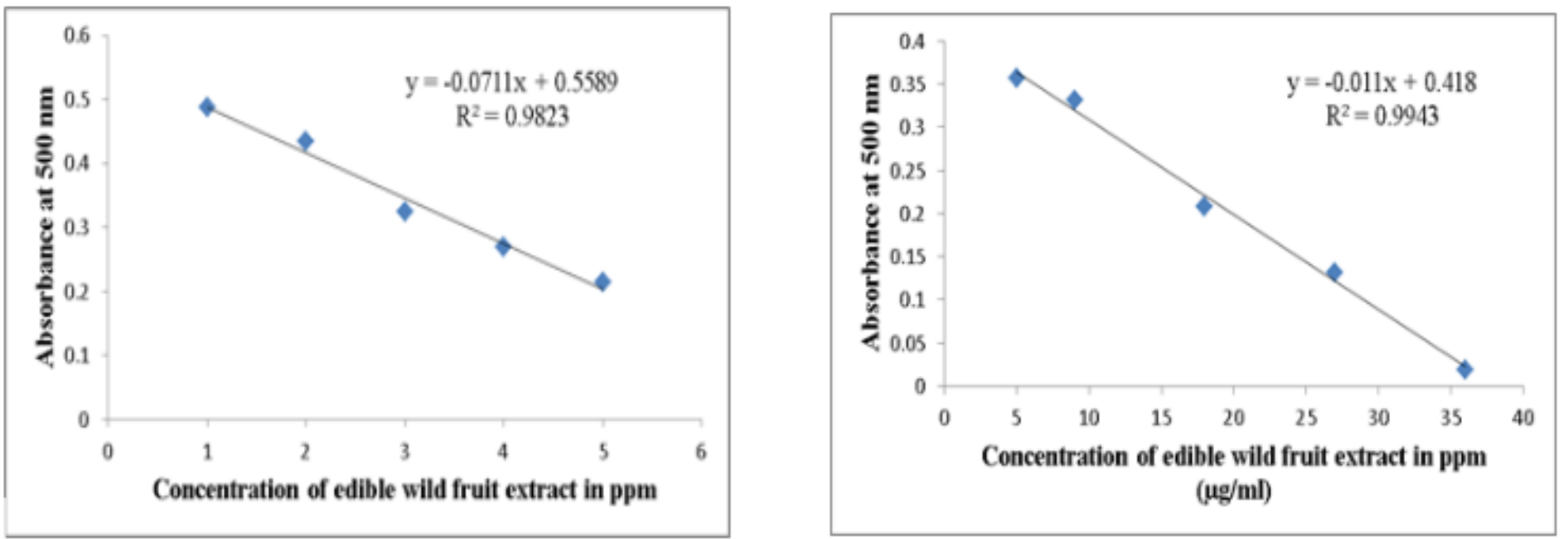

Figure 5

Calibrations curve for Phytic acid determination 